\title{
Comment
}

\section{Takeover Defense Tactics: A Comment on Two Models*}

\author{
Jeffrey N. Gordon† and Lewis A. Kornhauser+†
}

One of the most important debates of current corporate law practice and scholarship is about the appropriate role of target management confronted with a takeover bid. The controversy turns on the identification of a criterion for evaluating takeovers and target management defensive tactics. An influential body of opinion contends that maximization of shareholder wealth is the appropriate criterion because, first, traditional notions of fiduciary duty generally require managers to act in the shareholders' interest, and, second, shareholder wealth maximization is seen as the best available proxy for social wealth maximization. ${ }^{1}$ On this view, takeovers

- O Copyright 1986 by Jeffrey N. Gordon and Lewis A. Kornhauser.

+ Associate Professor of Law, New York University.

H Professor of Law, New York University. We have had useful comments on a previous draft from William Carney, John Coffee, and Roberta Romano. The authors also gratefully acknowledge the generous financial support of the Filomen d'Agostino and Max E. Greenberg Research Fund of New York University School of Law.

1. Shareholder wealth maximization is not identical to social wealth maximization. First, a takeover can redistribute wealth in favor of shareholders without increasing the economic output of the firm. One example is a transaction that increases shareholder wealth solely through downward renegotiation of employee contracts. See Coffee, Shareholders Versus Managers: The Strain in the Corporate Web, $85 \mathrm{MicH}$. L. REv. (forthcoming 1986). Another example is a leveraged acquisition that increases shareholder wealth through a transfer from bondholders, rather than through management efficiencies. Second, a takeover can result in events that may impose externalities. Obvious examples of such events include the shutdown of an acquired firm's headquarters and the layoff of workers, which may severely affect surrounding communities. Shareholder wealth may increase through such efficiencies, but total social wealth might not also increase.

Nevertheless, shareholder wealth maximization remains a useful proxy for social wealth maximization. First, a transaction or set of transactions that does not satisfy the shareholder criterion is highly unlikely to satisfy the social criterion, so that sharcholder criterion wealth maximization becomes a necessary if not sufficient condition in the general evaluation of takeovers. Second, the shareholder criterion is subject to comparatively easy quantitative measurement through analysis of stock price movements. But of. Gordon \& Kornhauser, Efficient Markets, Costly Information, and Securities Research, 60 N.Y.U. L. REv. 761, 775-86, 825-30 (1985) (questioning models that serve as basis for stock price studies). 
are desirable because they can increase shareholder wealth in two ways: first, by moving assets to managers who can produce the greatest economic return from them; and second, by increasing pressure on current management to maximize economic return from assets under their stewardship.

From this starting point, management has only two justifiable options for responding to a takeover bid. ${ }^{2}$ Some argue that management should respond passively. Passivity will maximize shareholder wealth by increasing the returns to search for takeover targets, which raises the number of value-increasing bids. ${ }^{3}$ Others contend that management may abandon passivity, but only to the extent necessary to instigate an auction for the firm. An auction will ensure that the user who most highly values the target assets will gain control over them (without the transaction costs of successive sales) while maximizing the payoff to target shareholders. ${ }^{4}$ Which of these responses would in fact maximize shareholder wealth is a matter of dispute.

Those who favor permitting target management responses that instigate auctions must face the problem of the divergence of shareholder and target management interests in a takeover. ${ }^{6} \mathrm{~A}$ successful auction means that target managers will possibly lose their jobs and certainly their autonomy. In adopting tactics that would tend to produce an auction, management may

2. Of course, "target management responses" do not exhaust the available regulatory or corporate strategies. In particular, much of the legal literature considers ex ante controls on takeovers through "shark repellent" charter amendments, see, e.g., Carney, Shareholder Coordination Costs, Shark Repellents, and Takeout Mergers: The Case Against Fiduciary Duties, 1983 AM. B. Found. Res. J. 341 , and division of the tender decision into a decision to merge and a decision to tender, see, e.g., Bebchuk, Toward Undistorted Choice and Equal Treatment in Corporate Takeovers, 98 HARv. L. REv. 1693, 1747-64 (1985). These responses are ex ante in that the rules are in place before any acquiror makes a bid. Hence they define the conditions under which a takeover may occur.

3. Easterbrook \& Fischel, The Proper Role of a Target's Management in Responding to a Tender Offer, 94 HaRv. L. REv. 1161 (1981); Schwartz, Search Theory and the Tender Offer Auction, 2 J.L. Econ. \& ORGanization (forthcoming 1986).

4. Moreover, since first bidders generally make a toehold purchase of target stock, they will make a substantial profit even if they lose the ensuing auction. This provides sufficient incentives for search. See, e.g., Bebchuk, The Case for Facilitating Competing Tender Offers, 95 Harv. L. Rev. 1028, 1034-38 (1982); Bebchuk, The Case for Facilitating Competing Tender Offers: A Reply and Extension, 35 Sran. L. Rev. 23 (1982); Gilson, A Structural Approach to Corporations: The Case Against Defensive Tactics in Tender Offers, 33 STAN. L. REv. 819, 868-75 (1981); Gilson, Seeking Competitive Bids Versus Pure Passivity in Tender Offer Defense, 35 Stan. L. Rev. 51 (1982). But see Easterbrook \& Fischel, Auctions and Sunk Costs in Tender Offers, 35 STAN. L. Rev. 1 (1982); Schwartz, supra note 3. See generally Coffee, Regulating the Market for Corporate Control: A Critical Assessment of the Tender Offer's Role in Corporate Governance, 84 CoLum. L. REv. 1145, 1175-83, 1280-82 (1984) (summarizing auction arguments and proposals for regulatory reform).

5. The question is to a great extent an empirical one: whether takeovers serve principally as a means for improving performance by current managers (which favors passivity), or for transferring assets to the highest valuing user (which favors auction instigation). Similarly, one must estimate the costs of search relative to the costs of holding an auction. As auction costs rise relative to search costs, passivity becomes preferable, while if auction costs fall relative to search costs, action grows more desirable.

6. See Jarrell, The Wealth Effects of Litigation by Targets: Do Interests Diverge in a Merge?, 28 J.L. \& ECON. 151 (1985). 
be hoping to thwart the takeover altogether. On the assumption that target management will act in a self-interested way, how should we distinguish tactics that will increase shareholder wealth from those that will not?

Two recent papers propose to answer this question for a particular class of management defensive tactics: target firm buybacks of its own stock. The papers, Bradley and Rosenzweig, Defensive Stock Repurchases, ${ }^{7}$ and Macey and McChesney, A Theoretical Analysis of Corporate Greenmail, ${ }^{8}$ come to similar conclusions: Even assuming management self-interest, some but not all target stock buybacks may increase shareholder wealth because of the resulting auctions. More specifically, Bradley and Rosenzweig generally endorse target self-tender offers because they contribute to an auction process, but criticize target open market repurchases because they distort shareholder choice. Macey and McChesney offer a defense of target buybacks of bidders' stock-better known as greenmail-on a similar ground. Economic models, explicit in Bradley and Rosenzweig's article and implicit in Macey and McChesney's article, underlie the conclusions. Each model, however, makes key hidden assumptions. In exploring those assumptions, we conclude that for each article, the case for the particular defensive tactic is "not proved." Indeed, our analysis of each model strongly suggests the opposite: that target stock buybacks are unlikely to increase shareholder wealth as a general matter and, on a shareholder wealth criterion, should not be permitted as a defensive tactic.

Our analysis has a methodological component as well. Current scholarship in corporate theory has adopted, at least in part, an economic research strategy. To deepen understanding of a problem, scholars identify a few factors deemed important and build a simple model of the phenomenon. Policy conclusions for complex legal problems flow from the analysis of the simple model. The great advantage of this research strategy is that it forces scholars to specify assumptions which can then be tested against data when available and against one's intuitions of the world when data is unavailable. Specification of assumptions makes it easy to uncover implicit assumptions which also can be tested. In this spirit we criticize the models and assumptions used by Bradley and Rosenzweig and by Macey and McChesney in studying target stock buybacks. Their models have served extremely useful functions-clarifying assumptions and forcing deeper analysis - and thus have increased understanding of how to evaluate target management responses to takeover bids.

7. 99 HARV. L. REv. 1377 (1986).

8. 95 Yale L.J. 13 (1985). 


\section{Preliminaries}

To clarify the problem under analysis and the terminology used, we outline the sequence of events that precedes a target stock buyback. At time 0 , shares of the target company sell at some open market price $\left(\mathrm{P}_{0}\right)$. At time 1, some bidder (B) purchases some small number of shares $\left(\mathrm{s}_{\mathrm{gm}}\right)$ at $P_{0}$. At time 2, the bidder makes a tender offer at a price $P_{t, 2}$ for sufficient shares in the target to give it control. Shares must be tendered by time 4. At time 3, the prevailing market price of target shares rises in response to the bid, to price $P_{m, 3}{ }^{\circ} \mathrm{We}$ assume that at time 3 management causes the target to undertake one of three forms of stock buyback:

(1) Open market repurchases in which the target announces a program to repurchase a specified number of shares on the open market at the prevailing market price $P_{m, 3}$. These open market purchases are made on a first come, first serve basis;

(2) A self-tender offer in which the target announces a "tender offer" for its own shares; i.e., an offer to purchase a specified number of shares at an announced price, $P_{s t, 3}$. For present purposes, the most important respect in which a self-tender offer differs from an open market repurchase program is that all shareholders may participate pro-rata in a selftender; 10

(3) A targeted share repurchase, or "greenmail," in which the target repurchases the shares held by the acquiror at an above-market price, $\mathrm{P}_{\mathrm{gm}, 3}$. In the analysis of both open market purchases and self-tenders, we assume (without loss of generality and following Bradley and Rosen2weig) that the bidder owns no shares prior to the actual tender offer $\left(\mathrm{s}_{\mathrm{gm}}\right.$ is 0 ).

Development of legal policy with respect to target stock buybacks depends on several factors. First, we must articulate the goals that the law seeks to promote. Second, we must understand the tender offer process. Under what circumstances and at what price will potential acquirors make offers? With what form of repurchase, if any, and at what price, will management respond? And how will target shareholders choose among competing offers? Third, we must understand how different legal rules will influence each of these three questions.

9. The post-tender prevailing market price, $P_{m, 3}$, will depend on the bid. In the cases relevant to this discussion, the bid takes the form of a front-loaded, two-tiered bid, so that $P_{m, 3}$ will reflect a weighted average of the front end and back end offer prices. Bradley and Rosenzweig rely on a particular model of price determination for $P_{m, 3}$ that we do not dispute here. Bradley \& Rosenzweig, supra note 7, at 1390-93. Macey and McChesney also apparently rely on a version of this model. See Macey \& McChesney, supra note 8, at 20-21.

10. Other points of difference include that the self-tender offer must remain open for a specific time period, and that shareholders who have tendered their shares have certain withdrawal rights. Bradley \& Rosenzweig, supra note 7, at 1379-80, $1384-87$. 
Two criteria inform the legal approach to target stock buybacks (and to much of corporate behavior in general). First, the law seeks to maximize shareholder wealth. To this end, legal rules should promote the transfer of assets from "inefficient" managers to "efficient" managers and should induce greater efficiency from current managers. By definition, an efficient manager earns a higher return on each dollar of assets than an inefficient manager. Consequently, given two firms facing equal non-diversifiable risk, the share price of an efficiently managed firm will exceed that of an inefficiently managed one. ${ }^{11}$

Second, the law seeks "fair" management treatment of shareholders. "Fair treatment" encourages shareholder investment and comports with traditional notions of fiduciary duty. In the context of target stock buybacks, fair treatment most plausibly means that management actions must not favor wealth acquisition by one group at the expense of another. ${ }^{12}$ Differential treatment-discrimination-among shareholders creates the possibility, though not the inevitability, of such favoritism. Greenmail clearly discriminates among shareholders because management offers an above market price only to the acquiror. Open market purchases do not discriminate ex ante but discriminate ex post. At the time of the announcement, all shareholders have an equal chance of being first in line in the open market transaction. Not every one, however, can actually be first in line. Hence, some shareholders will succeed in reselling their shares to the target, while others will not. By contrast, self-tender offers are nondiscriminatory both ex ante and ex post. ${ }^{13}$ Each shareholder has an identical claim on corporate assets. Bradley and Rosenzweig's and Macey and McChesney's articles present two challenges: (1) Does discrimination redistribute wealth among shareholders? (2) Does discrimination increase aggregate wealth?

11. See, e.g., Gordon \& Kornhauser, supra note 1 , at 776-80 (explaining portfolio theory and asset pricing models).

12. "Fair treatment" may have another sense, however. It may imply merely that all shareholders are better off after the target's repurchase program than they were prior to the making of the interfirm bid. The value of their shares or the realized value of their transactions after the repurchase program exceeds the pre-tender open market price $P_{0}$. Fair treatment in this sense is closely allied to the sharcholder wealth maximization criterion; if no one has been made worse off, then total shareholder wealth must have increased. Under this criterion, fairness is a Pareto improvement over the pre-bid state. This second meaning of "fair treatment" is akin to the claim that an unequal gainsharing rule in corporate control transactions is in fact "fair." See Easterbrook \& Fischel, Corporate Control Transactions, 91 YaLE L.J. 698, 703-04 (1982). We have elsewhere questioned the fairness of unequal gain sharing. Gordon \& Kornhauser, supra note 1, at 830-33. For a discussion of "fair treatment" as "equal treatment," see Bebchuk, Toward Undistorted Choice and Equal Treatment in Corporate Takeovers, 98 HARv. L. REv. 1693, 1780-88 (1985).

13. We have assumed that every shareholder will react identically both to the open market repurchase program and to the self-tender. Of course, if some shareholder chose not to tender her shares, she would not receive an equal portion of the corporate assets. Because she chose not to tender, however, we would be reluctant to characterize the inequality as deriving from unfair treatment. 
Our analysis of the behavior of potential bidders, management, and shareholders rests on conventional microeconomic assumptions of rationally self-interested conduct. The potential for inefficient management rests on an additional assumption of asymmetric information. Current management has the most accurate assessment of the value of the firm's assets. To discover this value or to monitor management conduct is costly. Management may convert some of the value of the corporate assets to its own use, thereby reducing shareholder wealth. ${ }^{14}$ Thus as we said above, takeovers serve two desirable functions: to move assets to the managers who can derive the greatest return from them, and to increase management incentives to manage the firm in a way that maximizes shareholder wealth. But takeovers must also serve a subsidiary, albeit necessary, function: to reward those who uncover information showing that particular assets are not put to the best use.

The behavioral questions raised by target stock buybacks and their legal treatment are complex. Analysts must understand not only management's reasons for initiating the buyback and the likely shareholder response, but also whether the buyback will defeat the tender offer. Further, different legal rules may have different effects on the frequency and terms with which bidders make tender offers.

Both Bradley and Rosenzweig and Macey and McChesney assume that the bidder makes a two-tier, front-loaded tender offer. They assume so because theory suggests that such offers place the most pressure on shareholders to tender. Let us consider this argument now, since it will recur in our discussion.

The "front end" of a two-tier, front-loaded offer is a high price for $50.0001 \%$ of the target's stock, $\mathrm{P}_{\mathrm{tf}, 2}$. Some time after the success of the first tier, the bidder will pay a lower price for the remaining $49.9999 \%$ of the company, $\mathbf{P}_{\mathrm{tb}, 2}$. Legally, the second-tier price is bounded below by the appraisal value of the shares. ${ }^{15}$ We assume, along with Bradley and Rosenzweig and Macey and McChesney, that the appraisal rights are equal to the pre-tender open market price, $\mathrm{P}_{0}$. The bidder will, of course, offer this lowest possible price in the second stage. If every shareholder tenders at the first stage, the bidder purchases its shares on a pro-rata basis. Thus

14. We advert here to the problem of agency costs. See, e.g., Jensen \& Meckling, Theory of the Firm: Managerial Behavior, Agency Costs and Ownership Structure, 3 J. FIN. EcoN. 305 (1976). For a useful collection of recent work, see Principals and Agents: THE Structure of Business (J. Pratt \& R. Zeckhauser eds. 1985). A sophisticated survey of agency cost models is given in $O$. Hart \& B. Holmstrom, The Theory of Contracts 8-52 (Massachusetts Institute of Technology Department of Economics Working Paper No. 418, Mar. 1986).

15. Also constraining the second tier are fiduciary duty doctrines that restrict the acquiror's ability to pay less than the pre-tender open market price of $P_{0}$. Bradley and Rosenzweig want to challenge these assumptions. See infra notes 32-34 and accompanying text. 
if every shareholder tenders, the value of a two-tier tender is the average of the front end and the back end (the pre-tender open market price), that is, $P_{t, 2}=\left(P_{t f, 2}+P_{0}\right) / 2$, which exceeds the value of not tendering. If some do not tender, then tendering shareholders sell a greater portion of their shares at the first-tier price, and their profits from tendering rise. More important, in the absence of a means for coordinating shareholder response, the optimum shareholder strategy is to tender even if shareholders believe that the value of the tender is below the "true" value of their shares. (Such shareholders would be anticipating a market revaluation of the firm or, more likely, a higher bid from a third party.) A shareholder who fails to tender into a successful bid loses the difference between the weighted value of the bid and the back end price $\left(P_{t, 2}-P_{0}\right)$. A shareholder who tenders into an unsuccessful bid suffers no loss. Thus tendering "dominates" not tendering in this situation. ${ }^{16}$

With these preliminaries in mind we turn to the specifics of target stock buybacks.

\section{OPEN MARKET REPURCHASES}

Bradley and Rosenzweig consider two buyback strategies: open market repurchases and self-tenders. They find open market stock repurchases objectionable on the claim that the discriminatory effects on target shareholders will defeat value-increasing interfirm bids. On the other hand, Bradley and Rosenzweig claim that self-tenders are generally permissible because they do not distort shareholder choice (shares are purchased pro rata $)^{17}$ and because they create an auction for the firm's resources among competing management teams. In particular, Bradley and Rosenzweig contend that self-tender offers enable target managers to defeat valuedecreasing, but not value-increasing, bids. In this section we focus on open market repurchases.

Bradley and Rosenzweig's own example provides the easiest context in which to analyze their model of the distortion of shareholder choice by

16. The dominance of "tendering" over "not tendering" is a consequence of the implicit assump. tions on price formation made, implicitly, in both models. Both models assume that target shareholders have identical beliefs about the value of the firm. If one relaxes this assumption, other equilibrium strategies may exist. In particular, shareholders with sufficiently high estimates of the value of the firm might choose not to tender. See L. BEBchuK, A MODEL of THE OUTCOME of TAKeover BidS (Harvard Law School Program in Law and Economics Discussion Paper No. 11 (Nov. 1985)).

If markets are efficient, it is plausible to assume that shareholders (who are not insiders) estimate that the value of the firm is equal to the market price. After all, the efficiency of the market means precisely that investors cannot form a better estimate than the market. See Gordon \& Kornhauser, infra note 1 , at $770-71$.

17. This premise is subject to certain constraints regarding both the number of shares bid for and non-discrimination against the bidder. See infra text accompanying note 42 . 
open market repurchases. ${ }^{18}$ To summarize briefly: consider a target firm with 200 shares outstanding, trading at $\$ 40$ a share prior to the bid, and thus valued by the market at $\$ 8000$. The acquiror values the firm at a minimum of $\$ 10,000$ and makes a two-tier, front-loaded bid of $\$ 60$ for the first 100 shares, $\$ 40$ for the remaining shares. The prevailing market price of target shares will increase to reflect the expected value of a tendered share, $\$ 50$. Target management then defends with an open market repurchase of 120 shares at $\$ 50$, which reduces the value of the firm by $\$ 6000$. The bid is withdrawn and the value of the firm falls to $\$ 2000$, or $\$ 25$ a share. ${ }^{19}$ At best, the bidder will present a revised bid substantially below $\$ 50$. Thus the remaining shareholders will have financed the premium received by the lucky open market sellers. ${ }^{20}$

This scenario produces a very important result: Upon announcement of the open market repurchase program, target shareholders will sell their shares on the market rather than tender to the bidder. Selling "dominates" tendering, meaning that shareholders will sometimes do better by selling than by tendering, and will never do worse. A selling shareholder receives at least $\$ 50$ a share. A non-selling shareholder ends up with shares worth $\$ 25$. Thus, according to Bradley and Rosenzweig, an open market repurchase amounts to payout of a special dividend to selling shareholders that distorts the shareholder decision. This results in the defeat of a bid which would raise the value of the firm from $\$ 8000$ to $\$ 10,000$. Therefore, open market repurchases are objectionable.

Bradley and Rosenzweig's model and policy conclusions rely, however, on a buried assumption and a buried policy goal. The buried assumption is that the source of the gains to the bidder is simply better management of target resources, irrespective of the nature of the original mismanagement. ${ }^{21}$ The buried policy goal is that tender offers should be encouraged

18. Bradley \& Rosenzweig, supra note 7, at 1387-99.

19. The computation is: $\$ 8000$ pre-bid value of the firm, minus $\$ 6000$ payout, equals $\$ 2000$. This amount divided by 80 outstanding shares equals $\$ 25$ a share.

20. We follow the example of Bradley and Rosenzweig, but confess some perplexity over why the open market price at which the target repurchase occurs should be \$50. Presumably, if sharcholders believe the tender will succeed, none will sell on the market for less than \$50. If, however, the open market repurchase produces the expectation that the tender will not succeed, the open market price should fall to reflect both the expected failure of the bid and the dilution in value of the unrepurchased shares. Moreover, the recognition that the repurchase program will reduce the value of the unrepurchased shares should increase shareholders' willingness to sell and discourage others from buying. Overall, this argument suggests that the price will likely fall below $\$ 50$. On the other hand, considerations not related to the market may drive management's repurchase decision; hence, management may be supporting the $\$ 50$ price. Assumptions on the price formation process play a crucial, but unexplicated, role in the model.

21. Bradley and Rosenzweig do not distinguish among the following types of possible mismanagement: failure to derive maximum economic return from some or all assets within the firm; failure to recognize and act on synergy gains from combining some or all of the firm's assets with assets of other firms; and failure to obtain competitive prices in sales of assets to other firms. 
because they generally increase incentives for management to maximize shareholder wealth. Because they do not make these points explicit in their discussion, Bradley and Rosenzweig fail to explain why it is important that the particular $\$ 60 / 40$ bid succeed rather than that some valuemaximizing bid or transaction occur.

We find that these issues are best examined by focusing on the financing of an open market repurchase. For simplicity, assume that the repurchase will be financed through cash that has been generated by the sale of target assets to a third party. ${ }^{22}$ Two questions must be answered. First, are the assets in question mismanaged by the target? Second, do we expect the sale of the assets by the target to be mismanaged? The key assumption for Bradley and Rosenzweig is that the sale is mismanaged; they do not seem to dispute that assets will end up in the hands of the most efficient managers after the repurchase. Changing the mismanaged sale assumption tests the basis of opposition to open market repurchases.

To expand this point in terms of Bradley and Rosenzweig's example, consider that target management can mismanage such assets in three ways. It may universally mismanage assets, so that competent management could achieve $125 \%$ of present returns (the ratio of the bid to the pre-bid market price, $10,000 / 8000$ ). It may mismanage specific assets, so that the percentage of the gain obtained by competent management depends upon the ratio of such specific assets to all assets. It may mismanage in the refusal to approve a merger in which such assets would produce synergies.

Now consider what happens when target management sells assets to finance the repurchase. In the universal mismanagement case (Case I), management should be able to realize the competitive value of the assets sold; in other words, it should be able to obtain a price that reflects the value of the assets to competent management. Although a particular management may be unable to put assets to highest use, it does not follow that it will also mismanage a sale of such assets. Thus, in contrast to the example, target management could finance the purchase of 120 shares at $\$ 50$ a share without reducing the stakes of remaining shareholders. Management would sell assets valued in its hands at $\$ 4800$, but would realize the competitive price of $\$ 6000$. The remaining value of the firm under present management would be $\$ 3200$, or $\$ 40$ a share for the remaining 80

22. We also assume that shareholders have the opportunity to observe the financing decision, including the outcome of the asset sale, prior to their decision to sell or tender. If the shareholders do not have this opportunity, the analysis should depend upon shareholder beliefs about the degree of mismanagement of the sale as well as target management's actual competence in handling the sale. However, in the simple model of price formation used by Bradley and Rosenzweig, shareholder beliefs play little or no role. The analysis also applies where the repurchase is financed through the target's cash on hand, or, in a more complex form, where it is financed through debt. 
shares. However, a bidder could still enhance the returns from the firm's assets by $125 \%$. The value of the firm to the bidder would be $\$ 4000$, or $\$ 50$ a share. In other words, the bidder should leave open its $\$ 50$ a share bid. Thus this particular repurchase is not objectionable on shareholder wealth maximization grounds, because assets either have been or will be transferred to the most efficient managers. Nor is it objectionable on shareholder fairness grounds, because all shareholders have the opportunity to realize $\$ 50 \cdot$ a share, despite differential treatment. ${ }^{23}$ Thus the open market repurchase program does not distort shareholder choice. ${ }^{24}$

The specific asset mismanagement case (Case II) is more complicated. To illustrate, assume that $50 \%$ of the target's assets are mismanaged, so that competent management could achieve $150 \%$ of present returns from such assets. Under this assumption, the value of the target to the bidder is still $\$ 10,000$. Case IIA: Once again, target management sells its mismanaged assets at the competitive market price of $\$ 6000$, enough to finance the repurchase program. The remaining value of the firm in the hands of present managers is $\$ 4000$, or $\$ 50$ a share. Shareholder wealth has been maximized because assets are now in the hands of the most efficient managers. Despite the differential treatment, all shareholders are equally well off; some shareholders have received a payment of $\$ 50$ a share, and others hold shares now worth $\$ 50$ each. ${ }^{25}$ The effect of the repurchase program may be to defeat the bid-because the value of the target has already been maximized, not because wealth effects have distorted shareholder choice.

Case IIB: Target management sells its well managed assets for $\$ 4000$, and another $\$ 1333$ of mismanaged assets for $\$ 2000$, to finance the repur-

23. In the real world, it is ordinarily preferable to realize $\$ 50$ now rather than $\$ 50$ later. However, the Bradley and Rosenzweig model avoids this complication by assuming that at all times after the tender offer is announced, the prevailing market price will be $\$ 50\left[P_{t, 2}=\left(P_{t l, 2}+P_{0}\right) / 2\right]$, and that shareholders will be indifferent between selling and tendering. An open market repurchase program provides additional impetus to sell rather than tender.

24. It might be more plausible to assume that the target mismanages the assets to a greater degree than it mismanages the sale, but that it still fails to realize full value for the assets. In that case, the sale of assets will dilute the value of the remaining shares to below $\$ 40$ per share, but the tender offer will still be desirable for the acquiror. Note further that even under Bradley and Rosenzweig's assumption of complete mismanagement of the sale in this case, the acquiror would still benefit from the acquisition. In target management's hands, the firm is worth $\$ 25$ per share, but in the acquiror's hands it is worth $\$ 31.25$ per share. Thus the repurchase will ward off the acquisition only if the transaction costs of completing the acquisition exceed $\$ 6.25$ per share. As the extent of the mismanagement of asset sales decreases, the difference between the value per share of the remaining assets to the acquiror and the value of the remaining assets to target management increases to the $\$ 10$ initial price differential.

25. The result in the text holds as long as the percentage of mismanaged assets is less than $50 \%$. If mismanaged assets exceed $50 \%$, then after financing the open market purchases on these facts, the target will still retain some mismanaged assets. The value of its shares will rise from $\$ 40$ a share to somewhat less than $\$ \mathbf{5 0}$ a share. The mismanaged assets still provide an incentive for the takeover, since the bidder would still be willing to pay $\$ 50$ a share. The bidder would withdraw the bid only if the expected gains were less than the transaction costs of completing the acquisition. 
chase program. The remaining value of the firm in the hands of present management is $\$ 2666$, or $\$ 33$ a share. On the assumption that competent managers could achieve $150 \%$ of present returns on the target's mismanaged assets, nothing in the scenario should lead the bidder to withdraw or revise its $\$ 50$ a share bid for the remaining shares. Once again, assets are transferred to the most efficient managers, and shareholders are equally well off. ${ }^{28}$

The final case (Case III), the refused synergy gains merger, is also complicated. Case IIIA: Assume that the target's assets would provide synergy gains to a wide variety of firms. Then, as in Case I, financing the repurchase program through a competitive sale of assets would not affect the bidder's $\$ 50$ bid and thus would not affect shareholder wealth. Case IIIB: Assume that the target's assets would provide synergy gains only to the bidder. Management would sell assets valued in its hands at $\$ 6000$. The remaining value of the firm would be $\$ 2000$, or $\$ 25$ a share. Assume, as a worst case, that the assets sold off were the source of the special synergy gains. The bidder withdraws the offer. In this case, assets would not be transferred to the most efficient managers, ${ }^{27}$ and the remaining shareholders would be disadvantaged. Their shares should trade for $\$ 25{ }^{2 \mathrm{~B}}$ This case generates a whipsaw effect on target shareholders.

Thus, on the assumption that the sale of target assets is well managed, we have shown that open market repurchases do not necessarily decrease shareholder wealth or treat shareholders unfairly. We have also identified, however, one limited case in which open market repurchases do raise these problems and thus produce distorted choice. ${ }^{29}$ Where open market

26. This result holds for a class of cases in which the target sells a mixture of well-managed and mismanaged assets to finance the open market repurchase.

27. Assuming that the special synergy assets are transferred intact to a purchaser, the bidder may transfer the bid, and eventually the assets will reach the party who can put them to best use. Of course, the transaction costs of additional bids reduce efficiency gains.

28. Case IIIB is the limit of a series of cases in which the bidder sells special synergy-gain assets to finance an open market repurchase program. Where only part of the special synergy assets were sold, the bidder would revise its bid, rather than withdraw it, to take advantage of gains still available. In a sense, all of these cases are inconsistent with the well-managed sale assumption, because in the instance of special synergy gains, the only well-managed sale is to the bidder.

29. This is not to say that a defensive open market repurchase program will not result in acquired shares. Sharcholders may indeed sell rather than tender, but they may do so for the arbitrage reasons that typically lead shareholders to sell rather than tender in most contested takeover situations. See supra note 23 . The Bradley and Rosenzweig model, and our discussion, assume for simplicity that the probability of the bidder's success is 1.0 , and thus that the market price will be $\$ 50$. In fact, the probability is lower-as will be the prevailing price. Shareholders are willing to transfer the risk of a bid's failing to a specialized group of risk bearers, arbitrageurs, who stand to realize the difference between the market price and the bid. Insofar as the announcement of defensive open market repurchases and associated tacties decreases the likelihood of success, the spread between the market price and the bid should increase. The increased spread, of course, reduces the payoff to the shareholder who sells in the open market and, commensurately, the risk of dissipation of target assets; i.e., it reduces the whipsaw effect even if the rest of the Bradley and Rosenzweig model holds. 
repurchases are financed through disposal of assets that would produce synergy gains only for the bidder, target management destroys the bidder's objectives in initiating the offer.

Does this showing justify open market repurchases? The answer is no. Even on favorable assumptions about target management's skill in the sale of assets, target shareholders are never better off, and are sometimes worse off, than if the open market repurchases had never occurred. If shareholder wealth can only remain constant or decrease, then the transaction costs of open market repurchases, and any associated bidder response, are deadweight losses. In light of the desirability of encouraging tender offers, there seems to be no reason to permit a defensive tactic that will never increase shareholder wealth. ${ }^{30}$

This leads us to questions curiously unasked by Bradley and Rosenzweig. How do open market repurchases defeat or hinder bids? Why do targets make them? One possible explanation, derived from the discussion above, is that the sale of special synergy assets might eliminate the motivation for the bid, and the distribution of resulting cash through the open market repurchase avoids the risk to target management of an attractive cash hoard. ${ }^{31}$ Another possible explanation is that an open market repurchase quickly enhances the influence of a management-controlled or otherwise friendly block. In our hypothetical, if management owns 20 of the remaining 80 shares, its tactical position becomes stronger; at the limit of 41 shares, it becomes impregnable. But how does management avoid reducing its wealth in this way? Puzzles for another day.

\section{SELF-TENDERS}

Recall Bradley and Rosenzweig's argument in favor of self-tenders. First, they argue that unlike open market repurchases, self-tenders do not have the potential for discrimination among shareholders and therefore cannot distort shareholder choice as between self-tenders and interfirm bids. Second, self-tenders generally enhance competition among management teams for firm resources. Third, and most important, self-tenders

30. The only circumstance in which a defensive open market repurchase may conceivably serve shareholder interests is the case where target management realizes more in the disposal of assets than the bidder has offered. Since the value of the target to remaining shareholders would be enhanced by such an open market repurchase and associated asset sale, the shareholder's decision to sell would not be distorted. This case assumes at least a partial failure in the market for corporate control or, alternatively, target management's ability to exploit its superior knowledge of target assets with a third party purchaser. It seems improbable to us that very many target managements will be successful in this way. But this case does lead to the shareholder wealth maximization conundrum previously avoided: namely, whether defensive tactics that improve the lot of shareholders of a particular firm are nonetheless objectionable because such tactics discourage other bids and thus reduce shareholder wealth generally. See supra text accompanying notes 2-6.

31. See also infra note 41 (discussing distribution of cash hoard in self-tender). 
enable target managements to defeat value-decreasing but not valueincreasing bids. ${ }^{32}$

One immediate objection to self-tenders derives from the earlier discussion of the financing of open market repurchases. If the target finances the self-tender through the sale of special synergy assets, the bidder may simply withdraw its bid. Regardless of the self-tender price, shareholder wealth will decrease. In this sense, a self-tender can defeat a valueincreasing bid. One might, however, regard this example not as an objection to self-tenders per se, but to the preceding asset sale, which could have occurred anyway. Is there a more general and direct objection to selftenders?

First consider the general management competition argument offered in support of self-tenders. At the time of the interfirm bid, target management already has had an opportunity to demonstrate its ability to maximize returns. The willingness of an interfirm bidder to offer a premium over market price suggests that in some way target management has lost the competition. A self-tender does not replicate an auction process, in which the highest valuing user gains control of the assets. Target managers (unlike managers who attempt a management buyout) are spending the shareholders' money, not their own funds. As shown by the discussion of the financing of defensive stock repurchases, a self-tender would at best lead target management to sell assets to those who could manage them better. But such sales might dissipate target assets and impose deadweight transaction costs. A management competition argument is a poor justification for these risks.

Moreover, this particular competition is loaded in favor of target management. The strategic calculus of two-tier tender offers clearly favors bids that offer the highest front end and maximize the spread between the front and back ends. ${ }^{33}$ Thus A's bid of $\$ 70$ a share for $50.0001 \%$ of the

32. On the assumption that target management will mismanage the sale of assets, Bradley and Rosenzweig claim that the value-maximizing interfirm bid of $\$ 60 / \$ 40$ always defeats the self-tender, because the assets are worth $\$ 10,000$ to the bidder and only $\$ 8000$ in the hands of the target. Assuming, as Bradley and Rosenzweig do, that target and bidder compete for equal numbers of shares, the bidder can use its surplus of $\$ 2000$ to top any offer that the target is capable of making. Even when the assumption about the target's ability to sell assets is relaxed, the bidder has the edge because of its higher valuation of target assets.

33. See, e.g., M. Bradley \& E. Kim, The Tender Offer as a Takeover Device: Its Evolution, the Free Rider Problem, and the Prisoner's Dilemma 23-24 (Apr. 1985) (unpublished manuscript).

The discussion in the text, following Bradley and Rosenzweig, considers only the case initiated by a hostile two-tiered bid or a hostile partial bid, which has an implicit back end of the post-bid market price. It does not consider the case of a hostile "any-or-all" bid (in which the bidder bids for all shares at a uniform price). There is evidence that in a competition among third party bidders, an any-or-all bid generally prevails over a two-tier bid with a higher front end but a lower blended price. See SEC Office of Chief Economist, The Economics of Partial and Two-Tier Tender Offers, Securities Exchange Release No. 21,079 [1984] Fed. Sec. L. Rep. (CCH) I 83,637, at 86,926 (June 21, 1984). The dynamics of a self-tender versus an any-or-all interfirm bid might lead to a different result. First, 
target's stock and $\$ 50$ for the balance will defeat B's bid of $\$ 65$ a share for $50.0001 \%$ and $\$ 55$ a share for the balance, even though $A$ and $B$ equally value the target. ${ }^{34}$ In a competition between target management and an interfirm bidder, the crucial question will be what constrains target management at the back end. Interfirm bidders are constrained by appraisal statutes, fiduciary duty doctrines, and more recently, fair price charter amendments which assure target shareholders of at least the prebid price for their shares. ${ }^{35}$ In effect, any self-tender contains as a back end the value of the remaining shares. This back end is not constrained. Whatever liquidation and distribution occur in the course of a self-tender will be pro-rata, which will make it very difficult for holders of remaining shares, no matter how reduced in value, to object.

The result is that target management will almost always be able to structure a self-tender that defeats an interfirm bid, even where the bidder values the target more highly. For example, in the hypothetical under discussion, assume the bidder values the target shares at $\$ 50$ each. Appraisal statutes and fair price charter provisions set $\$ 40$ as the floor for the backend of a two-tier offer. The bidder's strongest offer is $\$ 60$ for the first 100 shares, $\$ 40$ for the balance. Assume, as do Bradley and Rosenzweig, that target management could not generate more than $\$ 8000$ for a competitive bid (an assumption which we, of course, challenge). Even so, target management can design a competing self-tender that will prevail: $\$ 65$ for 100 shares. The remaining shares, in effect the back end of its offer, are worth $\$ 15$ each.

target management is likely to tender shares; the hostile bidder may or may not tender shares. These decisions will affect the value after prorationing of the self-tender for other shareholders. Second, the self-tender may not thwart a hostile bid, but may merely lead to a lower price. In any event, the anyor-all interfirm bid does not present the distorted shareholder choice problems that concern Bradley and Rosenzweig, in particular the value-decreasing bid. See supra text accompanying note 32 .

34. Compare a bid by $A$ and a bid by $B$, both of which value the entire firm equally, but in which the front end of $A$ is higher than the front end of $B$. If even one shareholder fails to tender, tendering shareholders will do better tendering to A rather than B because each tendering shareholder will now receive more than his pro-rata share of the common valuation of the firm. Moreover, since the front end is paid out immediately and the back end somewhat later, after a take-out, the time value of money favors A's bid.

Implicitly, of course, we (and Bradley and Rosenzweig) assume that no more shareholders will tender to $A$ than to $B$. If, contrary to this assumption, more shareholders would tender to $A$ than to $B$, the value of a tender to $B$ might be higher than the value of a tender to $A$, because a greater percentage of shares tendered to $B$ are taken in the front end. Following the example in the text, assume 10 shareholders each holding 10 shares: if all shareholders would tender to A but only 6 to $\mathrm{B}$, each shareholder tendering to $A$ would receive $\$ 600$ after the blend of the front and back ends, but each shareholder tendering to B would receive approximately $\$ 630$. This point, however, may be more relevant for a party trying to design the strongest initial bid than for a party anticipating an auction. Only one bid can succeed in the A versus B case (although, ironically both the self-tender and interfirm tender could succeed), and a shareholder can tender to only one bid. If the shareholder expects that either bid would draw more than $50 \%$, the dominant strategy would be to tender to $\mathrm{A}$.

35. Fair price charter amendments generally mandate that shareholders receive equivalent consideration in both parts of a two-tier bid, in effect eliminating the front load. 
Bradley and Rosenzweig have two responses to this objection. ${ }^{36}$ First, they question whether a bidder is in fact constrained by appraisal statutes or fair price charter provisions, which operate only where the bidder follows up a front-loaded offer with a take-out of the back end. They argue that because a bidder can delay paying off the back end, it can lower the effective price through undetectable self-dealing over time. Thus target managers do not have a competitive advantage over bidders in this respect. Apart from whether such behavior by a putative majority shareholder should be condoned, Professor Carney persuasively argues that the triggering take-out will almost always occur shortly after the bid is accepted. In particular, well-drafted fair price charter amendments operate to force a take-out at virtually the first instances of self-dealing, at least some of which will be detectable. ${ }^{\mathbf{3 7}}$

Bradley and Rosenzweig's second response to this objection is that appraisal rights and fair price charter provisions should cease to operate in the wake of a defensive self-tender. ${ }^{38}$ But this "modest proposal" would work a major change in corporate law. The purpose of appraisal rights and fair price charter provisions is to protect minority shareholders in corporate control contests. Presumably, Bradley and Rosenzweig would agree that these protections are part of a shareholder bargain, whether implicit (the "standard form" appraisal statute) or explicit (the charter provision). To abrogate such protections on the basis of conduct by target management would defeat their express purpose.

Finally, we must ask, what is the payoff for the assumptions and institutional changes that Bradley and Rosenzweig require? The payoff is the availability of the self-tender as a weapon, if not the ultimate weapon, against a value-decreasing bid. Two examples of such bids are an explicit two-tier bid in which the front end is above the prevailing market price but the back end is below (Gase A), and an implicit two-tier bid by a "corporate raider" who offers a premium to acquire majority ownership but then will self-deal or otherwise expropriate the wealth of remaining shareholders over time (Case B). In such circumstances, since the firm is

36. Bradley \& Rosenzweig, supra note 7, at 1419 n.150.

37. Carney, supra note 2, at 383-84. Moreover, many lawyers would be surprised at the Bradley and Rosenzweig claim that "Only a few courts recognize majority shareholder fiduciary obligations to the minority." Bradley \& Rosenzweig, at 1415 n.138. See, e.g., Weinberger v. UOP Inc., 457 A.2d 701 (Del. 1983) (enforcing majority shareholders' fiduciary obligation to minority in context of takeout merger); Sinclair Oil Corp. v. Levien, 280 A.2d 717, 720 (Del. 1971) (parent owes fiduciary duty to subsidiary); American LaW Institute, Principles of Corporate Governance: Analysis AND Recommendations, $\S 5.14$ (Tent. Draft No. 3, Apr. 13, 1984). Apart from the trigger of target charter amendments, many bidders will want to effect a take-out quickly as part of their plans to finance the transaction, for example, through partial liquidation of target assets.

38. Bradley \& Rosenzweig, supra note 7, at 1419 n.150. 
valued more highly in the hands of target management than by the valuedecreasing bidder, a self-tender will prevail.

In short, Bradley and Rosenzweig assume that alternative deterrents to a value-decreasing bid, namely, legal rules designed to prevent "raiding," and the market for corporate control, are unreliable. We have already discussed briefly how fiduciary duty rules and fair price charter provisions might limit the bidder's ability to offer explicitly or implicitly a back end price below the pre-bid market price. More important is the market for corporate control. Take Gase A, the explicit value-decreasing bid. If the gaming dynamics of such a bid would indeed constrain shareholders to tender, then presumably the prevailing market price of the target's shares would fall below the pre-bid price. ${ }^{39}$ The price change should alert other potential bidders, who, with very little investment in information, would realize the existence of an undervalued firm and enter the bidding. To suppose otherwise requires an assumption of large scale failure in the market for corporate control that seems very unrealistic.

Turn now to Case B, the implicit value-decreasing bid. Bradley and Rosenzweig seem to hypothesize a situation in which target management knew of the bidder's nefarious back end intentions (and so would be justified in initiating a self-tender), but the market did not (and thus did not emit its price signal to corporate control arbitrageurs as in Case A). This scenario seems, in general, highly implausible. Presumably target management would attempt to inform the market of the character of the bidder; the market price should reflect whether target management or the bidder has more credibility. If the conjecture has any force, it is only in the case of very small firms, perhaps not exchange-listed, as to which the market may not be well-informed..$^{40}$ But we should not let these conjectural problems in the smallest end of the market, with the least welfare implications, drive our conclusions. ${ }^{11}$

39. The price will fall because the prevailing market price will be a weighted average of the front and the back ends (assuming a probability of success of the bid of 1.0). It is also the price movement predicted by the more formal account in Bradley \& Rosenzweig, supra note 7, at 1390-93.

40. In general, the conjectures by Bradley and Rosenzweig about the failure of competitive markets in corporate control seem likely to apply only where the targets are small, because the relatively fixed costs of presenting a bid may be high, on a percentage basis, in comparison to the gains.

41. One reader of an earlier draft of this paper suggested that self-tenders may protect against "bootstrap" acquisitions in which the bidder proposes to finance the transaction entirely with the target's cash hoard and loans secured by the target's assets. Since the bidder's only risk is the transaction costs associated with making the bid, the argument goes, the incentives to undertake such a raid will be very high in the absence of a defensive tactic like the self-tender. This argument is not persuasive in our view. Even if one accepted the controversial assumption that such transactions would not lead to more efficient management of target assets, the case for the self-tender is not made. A target sitting atop a large cash hoard could simply pay out a special dividend to shareholders, which, unlike the defensive self-tender, would not discriminate against the bidder who forced management to disgorge this underutilized cash. (The discrimination would arise from the bidder's unwillingness to tender its shares.) 
The broader question that Bradley and Rosenzweig raise for corporate law scholarship is the appropriate use of law and economics models as a basis for policy prescriptions. The initial power of their model stems from its strong policy conclusions, apparently based on existing arrangements, about controversial target defensive tactics. Bradley and Rosenzweig boldly assert that a target's open market stock repurchase in response to a tender offer is objectionable, but that another form of defensive stock buyback, the self-tender, is not objectionable-indeed, that it serves a compelling purpose. Then the qualifications begin: First, the self-tender must be for no fewer than the number of shares in the interfirm bid. Second, it must not discriminate against the interfirm bidder. Both of these changes diverge from present arrangements. Finally, the rabbit emerges from the hat-in the form of a footnote:42 The scheme works only if accompanied by an additional significant and highly controversial change-the abrogation of appraisal rights and fair price charter provisions. Without these changes, self-tenders could become a major abuse. Not only do we find Bradley and Rosenzweig's model limited in application, we also question the gain that would arise from their policy prescription. Absent assumptions about radical market inefficiencies, the potential gains are likely to be very small and the potential losses very high. Yet all this becomes clear only after laborious unraveling.

\section{Greenmail}

A targeted share repurchase, or greenmail, is the buyback of the shares owned by a particular shareholder of the target who has made, or threatened, a takeover bid. The greenmail payment is typically at a premium over the prevailing market price. ${ }^{43}$ Macey and McChesney contest the standard account of greenmail which argues that greenmail serves management entrenchment objectives only; that is, that management, which has mismanaged target assets, pays greenmail in order to perpetuate its ability to exploit the target." According to this account greenmail should be prohibited because it decreases shareholder wealth and discriminates unfairly among shareholders in the distribution of corporate assets. ${ }^{45}$

42. Bradley \& Rosenzweig, supra note 7, at 1419 n.150.

43. Some would say that a buyback of the bidder's stock at any price over the pre-bid price, $P_{0}$, constitutes greenmail. Others, particularly target managements, would limit greenmail to a payment at more than the prevailing market price at the time of the payment, $\mathbf{P}_{\mathrm{n}, 3}$. The choice must depend on one's beliefs about the effect of the payment of greenmail on the post-payment share price. If the share price falls to $P_{0}$, the appropriate benchmark price is $P_{0}$, at least when adopting a criterion based on equal treatment of shareholders.

44. See generally Note, Greenmail: Targeted Stock Repurchases and the ManagementEntrenchment Hypothesis, 98 HARv. L. REv. 1045 (1985) (proposing prohibition of greenmail).

45. See Macey \& McChesney, supra note 8, at 14-15. 
Macey and McChesney contend, in contrast, that greenmail, although discriminatory, may maximize shareholder wealth in a "fair" way. They see greenmail as a step occasionally necessary to instigate an auction for the target. Macey and McChesney's argument has a theoretical and an empirical prong. First, they offer a hypothetical transaction in which a greenmail payment increases shareholder wealth because another bidder arrives offering a higher price. Second, they point to empirical evidence demonstrating that while on average the value of greenmail-paying targets declines after the payment of greenmail (relative to $P_{m, 3}$ ), the value of some targets increases (relative to $P_{0}$ and even to $P_{m, 3}$ ). These facts, they suggest, confirm that their hypothetical transactions sometimes occur. On the basis of this two-pronged argument, Macey and McChesney argue that the standard policy recommendation proscribing greenmail should be reconsidered. While they do not advocate a specific rule, their further arguments that greenmail neither discourages the production of information about undervalued firms, nor wastefully consumes real resources, suggest that they favor a legal rule permitting greenmail under some circumstances. ${ }^{48}$

Yet arguing against a prohibition of greenmail requires more than simply demonstrating that some value-increasing greenmail transactions may exist. It requires as well an alternative greenmail rule that will produce, over all transactions, more gains than losses. To evaluate the feasibility of any such rule requires that one examine Macey and McChesney's implicit model with regard to the full range of potential transactions. Thus we believe that Macey and McChesney's implicit model, like Bradley and Rosenzweig's, requires elaboration. .7 $^{47}$

46. In conversation, Jon Macey has suggested that he opposes a general proscription of greenmail. He would prefer to allow courts to articulate a legal rule that permits all, and only, those payments that promote shareholder wealth maximization.

47. Macey and McChesney's analysis may be motivated by a misunderstanding of the empirical literature on greenmail. Conceding that the literature shows that on average losses outweigh gains relative to $P_{m, 3}$, Macey and McChesney nevertheless infer that the existence of some transactions associated with gains demonstrates the desirability of some greenmail payments. Macey \& McChesney, supra note 8 , at 47-48. However, this inference misperceives the statistical techniques in the empirical literature. Such studies merely determine to what extent an event, such as a greenmail payment, is associated with a change in a firm's share price. But price changes are noisy signals, often affected by significant factors different from the event under study, i.e., confounding events. For example, a firm may make another important announcement on the same day of the greenmail agreement, such as a proposed recapitalization or unexpected earnings. Thus it is important to examine the price effects for many firms in order to distill the extent of the association and to filter out factors extraneous to the studied event. Averages are critical in this process. See Romano, Law as a Product: Some Pieces of the Incorporation Puzzle, 1 J.L. Econ. \& ORG. 225, 266 (1985) ("Because the event study methodology groups the stocks of firms undergoing the specified event into one portfolio, the variable of interest is an average residual."). To sustain their claim that greenmail payments on occasion have been desirable for shareholders, Macey and McChesney would have to examine individual transactions and explain how the greenmail payment led to shareholder gains. Compare Lease, McConnell \& Mikkelson, The Market Value of Control in Publicly-Traded Corporations, 11 J. FIN. EcoN. 439 
In Macey and McChesney's model, greenmail will be desirable for shareholders only (1) when target management has more favorable beliefs than the initial bidder about the arrival of other, higher-valuing bidders, and (2) when those beliefs are more accurate. ${ }^{48}$ Unless both of those conditions are met, a greenmail payment is likely to decrease shareholder wealth. Because information about the value of the target and the likelihood of other bidders is not equally shared by target management and an initial bidder, it is important to consider which party is likely to have superior information. In this regard the analysis must separately consider conscientious management (which always acts in the interest of the shareholders) and self-interested management (which exploits its agency relationship with shareholders to its own advantage).

Our objections become clearer in the context of Macey and McChesney's own example. ${ }^{4}$ The target company has 101 shares outstanding with the pre-tender market price of $\$ 30$. An acquiror $\left(B_{1}\right)$ values the assets at $\$ 37$ per share. First, it purchases one share at $\$ 30$. It then makes a front-loaded two-tier offer of $\$ 40$ for 50 shares, and $\$ 30$ for the remaining 50 shares. Under this set of facts, the bid is desirable for both the acquiror and the shareholders. Each shareholder, if all tender, realizes a profit of $\$ 5$ per share; the acquiror realizes a profit of $\$ 2$ per share, for a total of $\$ 207 . .^{50}$ In this case, payment of greenmail means a management offer of more than $\$ 30$ for the single share held by the acquiror in exchange for a withdrawal of its tender offer.

According to Macey and McChesney, such a greenmail payment will maximize shareholder wealth if a potential third party $\left(B_{2}\right)$ exists who values the target's assets at more than $\$ 37$ per share. In their example, $B_{2}$ values the target at $\$ 39$ per share. Macey and McChesney's argument has two steps. First, greenmail is necessary because the acquiror's front-loaded offer will induce shareholders to tender even if a higher bid is likely, so long as the higher bid is not yet made. Second, there exists a greenmail payment that the acquiror would accept and which would yield to shareholders, after an acquisition by $B_{2}$ at $\$ 39$ per share, a profit (net of the greenmail payment) of more than $\$ 5$ per share.

(1983) (event study aggregating all firms with dual class common stock) with Lease, McConnell \& Mikkelson, The Marhet Value of Differential Voting Rights in Closely Held Corporations, $57 \mathrm{~J}$. Bus. 443 (1984) (study of six particular firms with dual class common stock).

48. This latter assumption is not equivalent to an assertion that target management has more accurate beliefs than the bidder about the value of the firm rather than about the emergence of other bidders. Moreover, when target assets have synergistic relations with third party assets, target management may not have more accurate beliefs than the bidder about the target's value.

49. Macey \& McChesney, supra note 8 , at 21-22, 26-27.

50. The acquiror pays on average $\$ 35$ per share for one hundred shares which it values at $\$ 37$ per share, and thereby realizes a profit of $\$ 200$. In addition, the acquiror gains $\$ 7$ on the purchase of the first share for $\$ 30$. 
Our discussion in the introduction of the consequences of a front-loaded bid accords with the first step of Macey and McChesney's argument. They justify the second step in their argument as follows. Sale at $\$ 39$ per share to the third party provides an additional gain of $\$ 4$ per share (or $\$ 400$ total) to current shareholders over the acquiror's offer. The acquiror $\left(B_{1}\right)$ will gain only $\$ 207$ from successful acquisition. Therefore a greenmail payment between $\$ 237$ and $\$ 409$ for the acquiror's single share will make both the acquiror and target shareholders better off. ${ }^{51}$

Macey and McChesney's argument is incomplete as it stands. First, it conceals an assumption about when a mutually acceptable bargain between management and the acquiror can be struck. Isolating this assumption-that management has more favorable beliefs than the acquiror about the prospects of a third party bid-clarifies instances in which greenmail is desirable. Second, Macey and McChesney implicitly assume that target management can realize the $\$ 39$ per share valuation that exceeds the acquiror's $\left(B_{1}\right)$ valuation of the target. We question this implicit assumption.

Consider first the conditions under which management and the acquiror may reach a greenmail agreement. Such an agreement is possible only where management places a higher value on the firm's assets than the acquiror does. Otherwise, no greenmail payment that management would be willing to pay would persuade the acquiror to withdraw its bid. Here it is important to distinguish conscientious target management from self-interested target management. Conscientious management might value the target's assets more highly for two reasons. First, conscientious management assesses the prospects of a third party's offer ${ }^{52}$ more favorably than the acquiror. ${ }^{53}$ Second, conscientious management might assess the

51. When the third party acquires the target, it also acquires the $101 \mathrm{st}$ share held by the acquiror. In greenmail, the target repurchases this share from which the other 100 shareholders will derive the $\$ 39$ valuation of the third party. Thus the $\$ 409$ figure.

52. This assessment has two components: the likelihood of a third party making a bid and the value of the bid made.

53. See Macey \& McChesney, supra note 8, at 26-27. Macey and McChesney make this assumption implicitly. Its necessity may easily be demonstrated in the context of Macey and McChesney's numerical example. Suppose, for example, that the acquiror believes that no one will make a bid for the target greater than the $\$ 37$ per share value that it, the acquiror, places on the target. To induce the acquiror to part with its shares, target shareholders must give up at least the $\$ 2$ per share profit the acquiror was going to make on the transaction. For the greenmail transaction to be desirable, therefore, target shareholders must expect that a third party bidder will pay more than $\$ 37$ per share. Moreover, target shareholders must discount the expected third party bid by their assessment of its likelihood.

In general, one would expect the acquiror's $\$ 37$ per share valuation to incorporate its beliefs about the likelihood of a higher third party bid. Thus this discussion is more general than may initially appear. Macey and McChesney themselves suggest that the acquiror might have beliefs about third party bids independent of the acquiror's valuation of the assets in its own hands. Their discussion suggests that if acquiror and target had identical beliefs, then the acquiror would demand the total gain to be realized from the third party acquisition. This argument reasonably assumes that any third 
value of the target's assets as higher in its own hands than in the hands of the acquiror, and might expect to realize this higher value for shareholders through its own management efforts. ${ }^{\text {ot }}$ Self-interested management, on the other hand, would focus only on the value to itself of retaining control over the target's assets.

\section{A. Conscientious Management}

At the outset, we restrict our attention to conscientious management. Thus either management assesses the prospect of a third party's offer -more favorably than the acquiror or management believes that, in light of the acquiror's actions, management can increase the value of the firm to \$39. Consider the first alternative, that target management has more favorable beliefs about a third party bid than the acquiror. A mutually acceptable greenmail agreement while possible, is not necessarily desirable. Conscientious management may believe that the target should be valued at $\$ 39$ per share, but its expectations may be incorrect. Even though the acquiror has less favorable beliefs about the prospects of a third party bid, its beliefs may be more accurate.

Who has more accurate beliefs about the likelihood of a third party bid? The answer may depend upon the source of the gains in the transaction. The target's assets might be undervalued because they would react synergistically with the assets of other firms or because management is inefficient. In cases of synergistic undervaluation, target management might reasonably be unaware of potential synergies with other assets, while the acquiror more probably would understand the manner in which the target's assets would enhance operations like its own. While the initial bid may signal the existence of synergy gains, it is unlikely to inform target management of the extent or nature of such gains, at least not as fully as the acquiror is informed. If the acquiror has more accurate information than the target management, a greenmail payment would be undesirable.

If the undervaluation results from management inefficiency, target management arguably should have more accurate beliefs, since it has the most comprehensive knowledge about the target's current operations. But why would conscientious management be subject to undervaluation due to

party bid available to the target would also be available to the acquiror once it had taken over the target firm. Moreover, Macey and McChesney assume that while target and acquiror share beliefs about the third party's valuation of the target, they differ about the likelihood that the third party will make a bid. We maintain this assumption about beliefs; its relaxation would not alter the analysis.

54. Macey and McChesney do not consider this case, which provides a justification for greenmail payments in circumstances that they may find objectionable. The case is, however, implicit in their argument. 
management inefficiencies? Perhaps management is well-meaning but incompetent. Incompetence suggests that management requires a takeover to cure its own deficiencies; yet management's incompetence must not prevent its accurate valuation of the target's assets. This combination of incompetent management and accurate valuation is implausible.

Alternatively, management might be well-meaning but unaware. The acquiror's bid will have directed management's attention to its own deficiencies, which it now recognizes and assesses as more costly than the acquiror had believed. Thus management might believe either that it can convince a third party that the acquiror underestimated the extent of inefficiency in the target, or that it can now manage the firm in a more providential manner. Again, we have made conflicting assumptions about the quality of conscientious management. Here, management implements plans well, but does not always identify profit-maximizing policies to implement. While this may be plausible, it seems a thin reed on which to base legal policy concerning greenmail.

Suppose, however, that conscientious management has both more accurate and more favorable beliefs than the acquiror about the prospect of a third party bid. As in Macey and McChesney's example, assume that $\mathbf{B}_{2}$ values the target's assets at $\$ 39$ per share. How will target management extract all of this $\$ 39$ per share value for current shareholders?

Macey and McChesney assume that the third party bidder will pay $\$ 39$ per share even after the withdrawal of the acquiror's bid. Whether this occurs will depend upon the number of firms willing to bid for the target and the mechanism used for determining the target's price. But suppose only the acquiror and the third party have above-market valuations of the target. Once the acquiror has withdrawn from the bidding, the third party has no reason to offer its full valuation to the target. Indeed, the third party has no incentive to offer any more than the $\$ 35$ per share offered initially. In other words, Macey and McChesney must assume the existence of several bidders to provide competitive activity that would extract a $\$ 39$ bid. At bottom, their defense of greenmail relies on the assumption that it will instigate an auction. ${ }^{58}$

Once again, we should ask whether target management or the acquiror

55. For greenmail to be desirable, target management need only extract a value greater than the $\$ 37$ per share expected by the acquiror. The argument that follows in the text applies to this more generally phrased requirement.

56. Target management may be relying not on an auction, but on its competence at the negotiating table. Its bargaining position will be stronger with a large number of potential bidders. Absent multiple bidders, the results of the bargaining will defend upon the distribution of information between the target and the third party as well as their relative degrees of impatience and reputations for toughness in bargaining. See L. Kornhauser, A. Rubenstein \& C. Wilson, Reputation and THE "WAR OF ATtRItion" (New York University Department of Economics Working Paper, Feb. 1986). 
will have more accurate beliefs about the likelihood of such an auction. If we take seriously Macey and McChesney's belief that potential greenmailers can expertly identify undervalued firms and exploit that information in the market for corporate control, ${ }^{57}$ then the acquiror probably would have more accurate beliefs about the likelihood of a competitive bidding process for the target. Thus target management's more favorable beliefs are likely to be disappointed, and the payment of greenmail will reduce shareholder wealth.

Our analysis of the case of conscientious management thus far has followed Macey and McChesney in not considering the possible importance of financial intermediaries such as investment bankers. ${ }^{58}$ Arguably, financial intermediaries improve the accuracy of target management beliefs because they have better information, especially regarding potential synergy gains, about firms other than the target. Conscientious target management may also give the intermediary better information than that available to the acquiror about the extent of its own mismanagement. On the other hand, the introduction of financial intermediaries may have little net impact. First, presumably the bidder will also have access to financial intermediaries' information about other firms; the desirability of greenmail requires more accurate, not equally accurate, target management beliefs about a third party bid. Second, as noted above, conscientious management is unlikely to be aware enough of its deficiencies to be able to reveal them to the financial intermediary but not be able to cure them. Third, the financial intermediary is unlikely to have significantly better information about special synergy gains than that available to the acquiror. Thus even allowing for the use of financial intermediaries, we cannot conclude a priori that when conscientious target management has more favorable beliefs, it will also have more accurate ones. As the succeeding discussion shows, our doubts grow if we admit the possibility of self-interested management.

\section{B. Self-Interested Management}

In this case of self-interested management, an agreement does not depend on management's having more favorable beliefs about the prospects of a third party bidder. Rather, greenmail may be paid if the value to management of retaining control of the target exceeds the value of the target to the bidder.

Management's valuation may be higher than the bidder's for two rea-

57. Macey \& McChesney, supra note 8, at 31 .

58. For a useful discussion of the role of investment bankers in corporate control contests, see Note, Investment Bankers' Fairness Opinions in Corporate Control Transactions, 96 YALE L.J. 119, 121-24 (1986). 
sons. First, management may simply be converting to its own use value that should go to the shareholders. With this motive, management will pay greenmail only if the acquiror has underestimated the extent of management inefficiency or self-dealing, so that even after the payment there remains convertible value for management. Alternatively, management may simply assign non-economic value to its control over the target by an amount that will exceed the bidder's valuation. In either case, management must believe that the greenmail payment will forestall a subsequent takeover. If self-interested management believed that payment of greenmail would lead to a later acquisition by a third party, it would have no interest in paying greenmail.

To defend the payment of greenmail by self-interested management, one must argue that while management has a more accurate and more favorable estimate of the extent of its own inefficiency than the acquiror, it has a less accurate and less favorable estimate of the likelihood of a third party takeover than is warranted. How could this be? Macey and McChesney suggest that the payment of greenmail signals the undervaluation of the target to other potential bidders. ${ }^{58}$ This suggestion alone, however, does not sustain the argument for two reasons.

First, the greenmail signal is quite noisy. Other investors must determine the cause of the undervaluation. Is it target management inefficiency or synergistic gains? If the acquiror operated in only one line of business, others in that line of business might be able to easily determine the synergistic possibilities of the target's assets. If, however, the acquiror were a conglomerate, its bid would carry much less information. Not only might its bid have been prompted by target management's inefficiency, but even when the bid was motivated by synergy, other investors would not know the nature of the synergies available.

Second, in order to attract other potential bidders, the greenmail transaction must send a signal indicating that the target is undervalued by an amount greater than the acquiror believed. That is, the information carried by the bid followed by the greenmail payment must be greater than the amount of information in the acquiror's possession. Such a claim is implausible. An observer of the transaction could infer only that the acquiror believed that gaining control over target assets was worth less than the greenmail payment and that target management valued control at more than its share of the greenmail payment. Since most of the funds for the payment come from shareholders (indeed, if management owns no equity in the firm, then management bears none of the cost of greenmail),

59. Macey \& McChesney, supra note 8, at 24-25. 
the observer cannot even conclude for certain that anyone places a value on control over target assets in excess of the greenmail payment.

Furthermore, if we introduce financial intermediaries, the case for payment of greenmail by self-interested management grows even weaker. After all, we would expect that an investment banker would improve the accuracy of target management's beliefs about the prospects of a third party bid. Yet shareholders will want self-interested management to pay greenmail only in those cases in which it expects target management to have less accurate and less favorable beliefs than the acquiror.

Our analysis has suggested that the circumstances in which shareholders would want management to pay greenmail are extremely limited. Shareholders would want management to pay greenmail only (1) when conscientious management has more accurate and more favorable beliefs about the prospects of a third party bid, or (2) when self-interested management has more accurate and more favorable beliefs about the true value of the firm than the acquiror but less accurate and less favorable beliefs about the prospects of a successful third party bid. These circumstances are highly unlikely. Unfortunately, shareholders are likely to have less accurate beliefs about the value of the assets than either management or an acquiror. Shareholders are unlikely, then, to be able to draft contracts that identify the circumstances under which management should be permitted to pay greenmail. Instead, shareholders must either proscribe greenmail or rely on a legal rule to protect them. What legal rule is suggested by our analysis?

\section{Legal Rules}

The ideal legal rule would permit value-increasing greenmail payments and prohibit value-decreasing ones. Such a rule would be difficult, if not impossible, to formulate. Consider first a liability rule which would hold management responsible for losses to shareholders if the value of the firm did not increase after the payment of greenmail. Under this rule, management would rarely pay greenmail without express shareholder approval. Management, however, might often refuse to pay greenmail when shareholders, ex ante, would have desired the payment. The desirability of a greenmail payment depends upon an accurate assessment of the prospects of a better offer. A management facing prospective losses if the better offer does not appear would almost invariably reduce its risk by not paying greenmail.

Another class of legal rules would condition payment of greenmail on observable characteristics of the transaction. Our analysis of greenmail has identified some circumstances under which payments would be desirable, but the analysis has turned largely on characteristics that are difficult to 
specify, and on factual conjectures that seem unlikely. Indeed, our analysis suggests that the empirical instances of favorable greenmail payments cited by Macey and McChesney arise strictly by chance. In a certain number of cases, for example, self-interested management may simply be wrong in its unfavorable assessment of the likelihood of a third party bid. ${ }^{60}$ If chance elements predominate, then no legal rule is likely to identify ex ante desirable greenmail payments. ${ }^{61}$

We are tempted at this point to favor a rule proscribing greenmail entirely. The evidence shows that greenmail leads, in the aggregate, to shareholder welfare losses. Even assuming that some transactions may turn out well for shareholders, ${ }^{62}$ we have failed to devise a mechanism to separate desirable from undesirable transactions ex ante. Indeed, on the Macey and McChesney assumption of self-interested management, ${ }^{\text {es }}$ the case against greenmail seems fairly strong. Only the conscientious management case presents the possibility of a desirable greenmail payment, but that specific case and the required special circumstances are very difficult to observe.

One final possibility is a rule that would proscribe greenmail absent approval of the specific transaction by a majority of the disinterested shareholders. Apart from addressing the problem of target management self-interest, such a rule might induce production of information relevant to the source and extent of undervaluation. In making the greenmail signal less "noisy," this rule might actually improve prospects for a higher third party bid.

\section{Conclusion}

Our analysis of the cases presented by Bradley and Rosenzweig and Macey and McChesney in favor of target stock buybacks makes us skeptical of the claim that such transactions will increase shareholder wealth. On the other hand, the deficiencies may conceivably lie in the models presented, rather than in the transactions themselves. ${ }^{64}$ The policymaker's

60. Occasionally a greenmail payment may provide an unusually powerful signal of the extent of conversion of target assets by self-interested management. Some would explain the ousting of Disney management after its greenmail payment to Steinberg on this basis. Yet such cases hardly justify greenmail.

61. As part of a demonstration that any greenmail payment is desirable, Macey and McChesney would have to show not only that a particular greenmail payment was the source of an increase in shareholder wealth, see supra note 43 , but also that the greenmail decision was based on an accurate target management calculation of the kind they suggest.

62. See supra note 43.

63. Macey \& McChesney, supra note 8, at 16-17, 37-43. See also supra text accompanying notes $7-8$.

64. One reader of an earlier draft of this paper suggested that a better model of greenmail would account for the behavior of the greenmailer as a repeat player in a multi-period takeover game. Additional efforts to model greenmail are underway. See, e.g., I. DiWAN, J. WALDRoN \& K. WEIGELT, 


\section{Takeover Defense Tactics}

dilemma is that she cannot wait until completion of a fully developed model of a controversial transaction or practice before deciding how to respond. The attempt to construct and understand models can, however, deepen and refine the intuitions which lie behind the decision whether and how to intervene.

Managerial. Entrenchment and Greenmail: Endogenous Solutions to Free Riding in THE MARKet for Corporate Control (Salomon Brothers Center for the Study of Financial Institutions, New York University, Working Paper No. 368, Jan. 1986); Schleifer \& Vishny, Greenmail, White Knights, and Shareholder Interest, 17 RAND J. ECON. 293 (1986). 